\title{
High Expression of FcyII (CD32) Receptor on Monocytes in Dengue Infected Patients
}

\author{
Umi Solekhah Intansari ${ }^{1, *}$, Harina Salim $^{2}$, Usi Sukorini ${ }^{1}$, Mohammad Juffrie ${ }^{3}$ \\ ${ }^{1}$ Department of Clinical Pathology and Laboratory Medicine, Faculty of Medicine, Universitas Gadjah Mada/Dr. Sardjito General Hospital, \\ Jl. Farmako Sekip Utara, Yogyakarta, Indonesia \\ ${ }^{2}$ Department of Clinical Laboratory, Ade Muhammad Djoen Hospital, Jl. Pattimura No. 1, Tanjung Puri, Sintang, Indonesia \\ ${ }^{3}$ Division of Gastroenterology and Hepatology, Department of Child Health, Faculty of Medicine, Universitas Gadjah Mada/ \\ Dr. Sardjito General Hospital, Jl. Farmako Sekip Utara, Yogyakarta, Indonesia \\ *Corresponding author. E-mail: umintansari@ugm.ac.id
}

Received date: Jan 30, 2018; Revised date: Jul 12, 2018; Accepted date: Jul 31, 2018

\section{Abstract}

B ACKGROUND: Pathogenesis of severe dengue infection has not been elucidated. Immune complex of pre-existing antibodies and heterotypic dengue virus bind to FcyII (cluster of differentiation (CD32)) receptor (FcyIIR) on monocyte facilitates entry and replication of dengue virus. Aim of this study was to evaluate the expression of Fc $\gamma$ IIR on monocytes in patients infected with dengue and in healthy subjects.

METHODS: This study used a cross-sectional design that included patients infected with dengue who were hospitalized in Dr. Sardjito General Hospital, Panembahan Senopati Hospital, and Sleman Hospital, who met the inclusion criteria and selected consecutively. Examinations were completed using a lyse, no-wash method of flow cytometry. Computerized statistical analysis was conducted and was considered to be significant if $p<0.05$.
RESULTS: Sixty-five study subjects were divided into healthy subjects (24 subjects) and patients with dengue infection (41 subjects). There were no significant differences in hemoglobin $(\mathrm{Hb})$ and hematocrit $(\mathrm{Hct})$ values between the groups, but differences were found in the number of leukocytes, absolute number of monocytes and platelet count $(p<0.001,0.002$ and $<0.001$, respectively). The mean expression of FcyIIR monocytes in patients with dengue infection (208.77 \pm 32.06 median fluorescent intensity (MFI) $)$ and the healthy subjects $(124.03 \pm 47.76 \mathrm{MFI})$ with $p<0.0001$.

CONCLUSION: The mean expression of FcyIIR monocytes in patients with dengue infection was higher than in healthy subjects.

KEYWORDS: dengue infection, FcyII (CD32) receptor monocyte, flow cytometry

Indones Biomed J. 2018; 10(3): 256-62

\section{Introduction}

Dengue is an arbovirus that causes infection with any one of four related dengue viral serotypes. It is currently the most important mosquito-borne viral pathogen affecting humans, and it is emerging as a major threat to global health.(1) The best estimates available indicate that some 3 billion people live in parts of the world where they are at risk for infection and that approximately 40 million symptomatic episodes and approximately 20,000 deaths occur each year as a result of dengue. Currently, neither vaccines nor specific therapies are available for this disease, although both areas are currently the focus of intense research efforts. With expert supportive care, mortality rates have been reduced to very low levels, down to less than $1 \%$ in many centres of excellence for those with severe infections.(2) From 1968 until 2009, the World Health Organization (WHO) declared that Indonesia was the country with the highest rate of dengue haemorhagic fever (DHF) in Southeast Asia.(3) 
Dengue virus (DENV) has four serotypes: dengue (DEN)-1, DEN-2, DEN-3 and DEN-4, which target the liver, spleen, kidneys, lungs and bone marrow.(4) After being bitten by an infected mosquito, DENV enters the body and replicates within the mononuclear phagocytic cells (such as macrophages/monocytes). The incubation period of DENV infection is 7-10 days. The viraemic phase is followed by fever at which time the patient becomes infectious. This stage can be followed by a convalescent phase or progress to the plasma leakage phase that may cause DHF/dengue shock syndrome (DSS), that without proper treatment can be fatal. $(1,5)$

One of the central hypotheses proposed three decades ago for the pathogenesis of DHF/DSS was antibodydependent enhancement. Pre-existing antibodies to one serotype form immune complexes with heterotypic serotypes. These immune complexes bind to the FcyII (cluster of differentiation (CD)32) receptor (FcyIIR) on monocytes/macrophages that facilitates the entry, replication and spread of DENV, increasing the disease severity.(4)

Dengue infection is divided into four grades of severity according to the WHO 2011 criteria. The presence of thrombocytopenia $\left(<100,000\right.$ cells $\left./ \mathrm{mm}^{3}\right)$ along with haemoconcentration (increased hematocrit (Hct) $\geq 20 \%$ ) differentiates DHF from grades I and II of dengue fever (platelets $<150,000$ cells $/ \mathrm{mm}^{3}$ and increased Hct 5-10\%), while circulatory failure is considered DHF grade III and severe shock indicates grade IV or DSS.(6)

Monocytes and macrophages have long been suspected of being the primary target cells of DENV infection. A study by Kou, et al., stated that the FcyIIR expressed by monocytes plays an important role in the initial steps of immune enhancement in patients infected with DENV. $(7,8) \mathrm{Fc} \gamma$ receptors are immunoglobulin (Ig) receptors for IgG that provide the essential network for cellular effector mechanisms and humoral immunity, as well as playing an important role in immune function. Fc $\gamma$ IIR is an IgG receptor that binds the IgG1 subtype- 4 with low affinity and is involved in a number of immune responses including: cytotoxicity mediated by antibody-dependent cells; clearance of immune complexes; release of inflammatory mediators; and regulation of the formation of antibodies. $(9,10)$

Single point mutations at the gene position 131 (arginine (R131) or histidine (H131)) encoded by Fc $\gamma$ IIAR appear to bind IgG subclasses. The Fc $\gamma$ IIA-R/ R131 genotype receptor binds IgG1/3 and the FcyIIA-H/ H131 genotype receptor binds IgG2 efficiently. Based on this finding, Fc $\gamma$ IIAR polymorphisms may alter Fc $\gamma$ IIAR functions and may be associated with the variability of the immune response associated with the pathogenesis of dengue.(11) Earlier study showed that FcyIIR expression higher in secondary infection than primer.(12)

Nowadays, there is no data about the level of Fc $\gamma$ IIR expression in healthy individual. The objective of this study was to evaluate the expression of FcyIIR monocytes in patients with DENV infection and in healthy subjects.

\section{Methods}

This was an observational analytical cross sectional study that was conducted in the Pediatric Department of Dr. Sardjito Hospital, Yogyakarta, Panembahan Senopati Hospital, Bantul, Sleman Hospital, Sleman, Clinical Laboratory Installation of Dr. Sardjito Hospital, Yogyakarta and the Faculty of Medicine at Universitas Gadjah Mada, Yogyakarta from September 2012 to January 2013. The inclusion criteria were patients with dengue infection included fever (body temperature $\geq 38^{\circ} \mathrm{C}$ ) for less than five days, and the $\operatorname{IgM} / \operatorname{IgG}$ dengue/nonstructural protein 1 (NS1)/polymerase chain reaction (PCR) were positive, whereas the exclusion criteria were if the sampling was not feasible; if the data were incomplete; and if there were co-infection with other infectious diseases obtained by anamnesis, communication with clinicians and medical records. The inclusion criteria for the control group was a normal complete blood count (CBC) result, and the exclusion criteria was a history of rheumatoid arthritis.

This study used ethylene diamine tetra acetate (EDTA) blood and Fc $\gamma$ IIR expression was determined in 24 hours after sampling because sample stability only 48 hours. Expression of monocytes with FcyIIR in whole blood was determined using monoclonal antibody CD32 fluorescein isothiocyanate (FITC) (Cat No. \#552883), CD14 PE (Cat No. \#562691) and CD45 PerCP (Cat No. \#347464) with a BD FACS Calibur flow cytometry (BD Biosciences, San Jose, CA, USA) and Cell-Quest software (BD Biosciences). The calibration test of the flowcytometer was carried out prior to the examination of the sample material by using CaliBRITE beads FACS Comp (BD Bioscience). Coefficient of variance of intra-assay precision on the expression of Fc $\gamma$ IIR monocyte was $3.41 \%$.

The collected data were checked for completeness and accuracy, then coded and tabulated and inserted into the computer. The subject characteristic data were presented descriptively in the form of mean and standard intersection for continuous data, while the categorical data 
were presented in the form of frequency and proportion. A mean test and proportion test between the characteristics of research subjects was performed.

Statistical analyses were performed using SPSS v.17.0 (SPSS Inc, Chicago, Illinois, USA). Continuous data were summarized using means for normally distributed data and median for abnormally distributed data. Ordinal and categorical data were summarized with ratios or proportions. Between-group differences were assessed using the MannWhitney test or independent T-test depend on normality. Statistical significance was considered if $p<0.05$.

This study was approved by Faculty of Medicine Universitas Gadjah Mada Ethical Commission Board with certificate number KE/FK/256/EC.

\section{Results}

Sixty-five subjects were included in this study, and among these 41 patients had dengue infection and 24 were healthy subjects. In the healthy subjects group, 11 participants $(45.8 \%)$ were $\leq 15$ years old and 13 participants $(54.2 \%)$ were $>15$ years; 12 participants $(50 \%)$ were male and 12 participants $(50 \%)$ were female. Among the patients in the dengue infection group, 18 participants (41.9\%) were $\leq 15$ years old were 23 participants $(53.3 \%)$ were $>15$ years old, also 22 participants (53.7\%) were male and 19 participants (46.3\%) were female (Table 1).
$\mathrm{CBC}$ test showed that there is no significant differences in hemoglobin $(\mathrm{Hb})$ and Hct values, but found significant differences in the numbers of leukocytes, the absolute number of monocytes, and platelet counts $(p<0.001,0.002$ and $<0.001$, respectively) (Table 2 ). There was a significant difference in Fc $\gamma$ IIR expression on monocytes between healthy subjects and patients with dengue infection, $p<0.0001$ (Table 3).

There were no cases of hematemesis/melena or shock in the patients in the dengue infection group. There was a significant difference of Fc $\gamma$ IIR between groups in hepatomegaly $v s$. non-hepatomegaly and ascites $v s$. nonascites, $p=0.005$ and 0.031 , respectively (Table 4 ).

Of the forty-one patients with dengue infection, 26 people were diagnosed with dengue fever and 15 with DHF. There was no significant difference between the groups in the mean FcyIIR expression of the monocytes, $\mathrm{Hb}$, number of leukocytes, the absolute number of monocytes and the day of fever. However, there was a significant difference in the increased value of the Hct and platelet counts ( $p=0.004$ and 0.004 , respectively) (Table 5).

There was no significant difference in the expression of Fc $\gamma$ IIR on monocytes by age group and gender, but a significant differences in the day of fever $(p=0.005)$ between the degue fever and DHF groups (Table 6). The mean of monocyte's Fc $\gamma$ IIR (CD32) expression was significantly different between days 3 and 4 of fever on post-hoc analysis ( $p=0.001)$.

Table 1. Study subjects' demographic and clinical data.

\begin{tabular}{|c|c|c|c|c|}
\hline Variable & Healthy Subjects & n $(\%)$ & $\begin{array}{c}\text { Patient with } \\
\text { Dengue Infection }\end{array}$ & n (\%) \\
\hline \multicolumn{5}{|l|}{ Age (years) } \\
\hline$\leq 15 ; \overline{\mathrm{x}} \pm \mathrm{SD}$ & $8.4 \pm 4.8$ & $11(45.8)$ & $8.7 \pm 4.3$ & $18(41.9)$ \\
\hline$>15 ;$ median $(\min -\max )$ & $34(19-50)$ & $13(54.2)$ & $22(16-54)$ & $23(53.3)$ \\
\hline \multicolumn{5}{|l|}{ Gender } \\
\hline Male & - & $12(50)$ & - & $22(53.7)$ \\
\hline Female & - & $12(50)$ & - & $19(46.3)$ \\
\hline \multicolumn{5}{|l|}{ Hospitalized at } \\
\hline RSUP Dr. Sardjito & & & & $23(56.10)$ \\
\hline RSUD P. Senopati & & & & $8(19.51)$ \\
\hline RSUD Sleman & & & & $10(24.39)$ \\
\hline The day of fever & & & $3(1-4)$ & \\
\hline Hospitalisation duration & & & $4(2-12)$ & \\
\hline
\end{tabular}

$\overline{\mathrm{x}}$ : mean; SD: standard deviation; min: minimum; max: maximum. 
Table 2. Haematological characteristics.

\begin{tabular}{lccc}
\hline \multicolumn{1}{c}{ Variables } & $\begin{array}{c}\text { Healthy Subjects } \\
(\mathbf{n}=\mathbf{2 4})\end{array}$ & $\begin{array}{c}\text { Patient with } \\
\text { Dengue Infection } \\
(\mathbf{n}=\mathbf{4 1})\end{array}$ & $\boldsymbol{p}$-value \\
\hline $\mathrm{Hb}(\mathrm{g} / \mathrm{dL}) ; \overline{\mathrm{x}} \pm \mathrm{SD}$ & $13.20 \pm 1.50$ & $13.74 \pm 2.03$ & 0.235 \\
$\mathrm{Hct}(\%) ; \overline{\mathrm{x}} \pm \mathrm{SD}$ & $39.81 \pm 4.02$ & $39.98 \pm 5.58$ & 0.886 \\
$\sum$ leukocyte $\left(10^{3} / \mu \mathrm{L}\right) ;$ median $(\min -\max )$ & $7.91(4.30-10.47)$ & $3.57(1.10-10.50)$ & $<0.001^{*}$ \\
$\sum$ abs. Monocyte $\left(10^{3} / \mu \mathrm{L}\right) ;$ median $(\min -\max )$ & $0.52(0.15-1.87)$ & $0.24(0.07-0.86)$ & $0.002^{*}$ \\
$\sum$ platelet $\left(10^{3} / \mu \mathrm{L}\right) ; \overline{\mathrm{x}} \pm \mathrm{SD}$ & $263.58 \pm 47.76$ & $89.78 \pm 48.41$ & $<0.001$ \\
\hline
\end{tabular}

Independent sample T-test $/ *$ Mann-Whitney, significant if $p<0.05$. abs: absolute

\section{Discussion}

Ribonucleic acid (RNA) of DENV has been isolated from the bone marrow in patients infected with DENV, indicating that the bone marrow and hematopoietic system were also the target of DENV. In addition, DENV was also recently isolated from polymorphonuclear neutrophil (PMN), monocytes/macrophages and dendritic cells.(13) Leukopenia and monocytopoenia in this study was similar with the study that that conducted by Kalayanarooj, et al., in Bangkok in children with a fever less than 72 hours, for whom neutropenia and monocytopoenia signified dengue infection vs. other fever illness.(14) Similar results were also obtained in a study from the Philippines in which 215 dengue patients had routine haematology checked on the fourth or fifth day of fever, which found 136 patients (63.3\%) had leucopoenia.(15)

Funahara, et al., proved that the DENV antigen can affect platelets directly without going through the immune responses.(16) A recent study conducted by Ghosh, et al., showed that DENV can directly interact and activate platelets. RNA and DENV particles had also been detected in platelets in patients infected with DENV, indicating that DENV was able to replicate in platelets by an unknown mechanism.(13)
Hepatomegaly was more frequently found in patients with DHF compared to dengue fever. Hepatic dysfunction could occur due to the direct effects of the infection or because of an immune response.(17) Interaction between the immune response and the impact on the integrity and function of the endothelial cells caused increased vascular permeability and plasma leakage.(18) Monocytes produced cytokines that caused the activation of endothelial cells that expressed adhesion molecules such as vascular cell adhesion molecule (VCAM)-1 and intercellular adhesion molecule (ICAM)-1.(19) Pleural effusion and ascites were suspected to have occurred because of the increased vascular permeability.(20)

The pilot study was conducted by Durbin, et al., during August 2005 - February 2006 in Nicaragua in children with DENV infection by using peripheral blood mononuclear cell (PBMC) obtained from most of the cells containing the dengue antigen expressed phenotype typical of activated monocytes, even at primary dengue infection. FcyIIR expression on monocytes in patients with DHF vs. dengue fever were significantly different, $p=0.01$.(21) In contrast with this study's results that showed no significant differences in FcyIIR expression on monocytes between dengue fever vs. DHF groups, the expression of FcyIIR on monocytes in dengue patients was likely influenced by the patterns of viraemia and the kinetics of the immune

Table 3. Monocyte Fc $\gamma$ II (CD32) receptor expression.

\begin{tabular}{lcccc}
\hline \multicolumn{1}{c}{ Variable } & $\mathbf{n}(\%)$ & $\begin{array}{c}\text { Monocyte's Fc } \gamma \text { IIR } \\
\text { (CD32) Expression } \\
\text { Mean } \pm \text { SD (MFI) }\end{array}$ & p-value \\
\hline Healthy subjects & $24(36.92)$ & $124.03 \pm 47.76$ & $<0.0001$ \\
Patients with dengue infection & $41(63.08)$ & $208.77 \pm 32.06$ & \\
\hline
\end{tabular}

Independent T-test, significant if $p<0.05$. 
Table 4. Comparison of the FcyII (CD32) receptor expression on monocytes of patients with dengue infection based on clinical symptoms of dengue infection.

\begin{tabular}{|c|c|c|c|}
\hline Variable & n $(\%)$ & $\begin{array}{l}\text { Monocyte FcyIIR } \\
\text { (CD32) Expression } \\
\text { Mean } \pm \text { SD (MFI) }\end{array}$ & $p$-value \\
\hline \multicolumn{4}{|l|}{ Hematemesis } \\
\hline Yes & $0(0)$ & - & - \\
\hline No & $41(100)$ & $208.77 \pm 32.06$ & \\
\hline \multicolumn{4}{|l|}{ Melena } \\
\hline Yes & $0(0)$ & - & - \\
\hline No & $41(100)$ & $208.77 \pm 32.06$ & \\
\hline \multicolumn{4}{|c|}{ Hepatomegaly $\geq 2 \mathrm{~cm}$} \\
\hline Yes & $8(19.51)$ & $187.92 \pm 18.39$ & 0.005 \\
\hline No & $33(80.49)$ & $215.55 \pm 33.53$ & \\
\hline \multicolumn{4}{|l|}{ Pleural Effusion } \\
\hline Yes & $5(8.20)$ & $191.54 \pm 31.60$ & 0.218 \\
\hline No & $36(87.80)$ & $212.74 \pm 32.64$ & \\
\hline \multicolumn{4}{|l|}{ Ascites } \\
\hline Yes & $3(7.32)$ & $178.54 \pm 14.92$ & 0.031 \\
\hline No & $38(92.68)$ & $212.65 \pm 32.71$ & \\
\hline \multicolumn{4}{|l|}{ Shock } \\
\hline Yes & $0(0)$ & - & - \\
\hline No & $41(100)$ & $208.77 \pm 32.06$ & \\
\hline
\end{tabular}

Independent T-test, significant if $p<0.05$.

response to dengue infection caused this study used subjects with various day of fever. Other study confirm that FcyIIR expression on monocytes was not related to clinical severity.

Dengue infection is the result of a multifactorial interaction between agents, the host, and the environment.
On the one hand, the immune response can be beneficial, but it may also be detrimental, which prompted the interest of the authors interested in understanding the involvement of genetic factors in these infections, namely genetic susceptibility.(16) Several studies have confirmed that

Table 5. Fc $\gamma$ II (CD32) receptor expression on monocytes, haematology variables and the day of fever based on the degree of severity.

\begin{tabular}{|c|c|c|c|}
\hline \multirow{2}{*}{ Variable } & \multicolumn{2}{|c|}{ Patient with dengue infection } & \multirow{2}{*}{$p$-value } \\
\hline & DF $(n=26)$ & DHF $(n=15)$ & \\
\hline Fc $\gamma \operatorname{IIR}(\mathrm{CD} 32)(\mathrm{MFI}) ; \overline{\mathrm{x}} \pm \mathrm{SD}$ & $217.05 \pm 33.38$ & $198.22 \pm 29.33$ & 0.069 \\
\hline Mean $\mathrm{Hb}(\mathrm{g} / \mathrm{dL}) ; \overline{\mathrm{x}} \pm \mathrm{SD}$ & $13.41 \pm 1.74$ & $14.30 \pm 2.42$ & 0.228 \\
\hline $\operatorname{Hct}(\%) ; \overline{\mathrm{x}} \pm \mathrm{SD}$ & $39.27 \pm 4.85$ & $41.21 \pm 6.66$ & 0.335 \\
\hline$\Delta \operatorname{Hct}(\%) ; \bar{x} \pm \mathrm{SD}$ & $4.35 \pm 1.81$ & $6.87 \pm 2.47$ & 0.002 \\
\hline Increase Hct $(\%) ; \bar{x} \pm S D$ & $12.22 \pm 5.56$ & $19.78 \pm 8.06$ & 0.004 \\
\hline Leukocytes count $\left(10^{3} / \mu \mathrm{L}\right)$; median (min-max) & $3.28(1.10-10.50)$ & $4.10(1.20-7.83)$ & $0.317^{*}$ \\
\hline$\sum$ abs. monocytes $\left(10^{3} / \mu \mathrm{L}\right)$; median $(\min -\max )$ & $0.33(0.07-0.86)$ & $0.22(0.08-0.85)$ & $0.192 *$ \\
\hline Platelet count $\left(10^{3} / \mu \mathrm{L}\right) ; \overline{\mathrm{x}} \pm \mathrm{SD}$ & $105.77 \pm 45.44$ & $62.07 \pm 41.3$ & 0.004 \\
\hline The day of fever; median (min-max) & $3(1-4)$ & $4(3-4)$ & $0.053 *$ \\
\hline
\end{tabular}

Independent T-test $/ *$ Mann-Whitney, significance if $p<0.05$. 
Table 6. Monocyte Fc $\gamma$ II (CD32) receptor expression in patients with dengue infection group based on age, gender, and the day of fever.

\begin{tabular}{lccc}
\hline \multicolumn{1}{c}{ Variable } & n (\%) & $\begin{array}{r}\text { Monocyte's Fc } \gamma \text { IIR } \\
\text { (CD32) expression } \\
\text { Mean } \pm \text { SD (MFI) }\end{array}$ & p-value \\
\hline $\begin{array}{l}\text { Age (years) } \\
\leq 15 \text { th }\end{array}$ & $18(43.9 \%)$ & $207.02 \pm 34.75$ & 0.599 \\
$>15$ th & $23(56.1 \%)$ & $212.62 \pm 31.92$ & \\
\hline Gender & & & \\
$\quad$ Male & $22(53.7 \%)$ & $202.73 \pm 34.22$ & 0.117 \\
Perempuan & $19(46.3 \%)$ & $218.76 \pm 29.87$ & \\
\hline The day of fever & & & \\
1 & $2(4.9 \%)$ & $203.43 \pm 52.96$ & \\
2 & $0(0 \%)$ & - & \\
3 & $22(53.9 \%)$ & $224.97 \pm 29.24$ & \\
4 & $17(41.5 \%)$ & $191.78 \pm 27.21$ & \\
\hline
\end{tabular}

Independent T-test $/$ " one way ANOVA, significant if $p<0.05$.

certain genetic polymorphisms may provide protection to individuals who suffer from DHF preventing DSS. Loke, et al., found that the variant homozygous arginine at position 131 of the Fc $\gamma$ RIIA genes have low capacity for opsonization IgG2 antibodies that provide protection for the DHF.(9) Furthermore, the interaction between the complex and the virus-antibody FcyRIIA (DENV/IgG1/ IgG3) was associated with the formation of an efficient phagolysosome to eliminate immune complexes and control the spread of virus.(11) antibody-dependent enhancement (ADE) hypothesis states that non neutralizing antibodies in secondary infection may enhances dengue infection. Higher Fc $\gamma$ IIR expression in dengue patients indicate secondary than primary infection.(12)

\section{Conclusion}

The mean expression of FcyIIR (CD32) on monocytes in patients with dengue infection was higher than in healthy subjects. Fc $\gamma$ IIR expression was not significantly different between dengue fever and DHF.

\section{References}

1. Malavige, GN, Fernando S, Fernando, DJ, Seneviratne SL. Dengue viral infections. Postgrad. Med. J. 2004; 80: 588-601
2. Martina BEE, Koraka P, Osterhaus ADME. Dengue virus pathogenesis: an integrated view. Clin Microbiol Rev. 2009; 22: 564-81.

3. Kementerian Kesehatan RI. Demam berdarah dengue. Buletin Jendela Epidemiologi. 2010; 2: 1-15.

4. Blackley S, Kou Z, Chen H, Quinn M, Rose RC, Schlesinger JJ, et al. Primary human splenic macrophages, but not $\mathrm{T}$ or B cells, are the principal target cells for dengue virus infection in vitro. J Virol. 2007; 81: 13325-34.

5. Clyde K, Kyle JL, Harris E. Recent advances in deciphering viral and host determinants of dengue virus replication and pathogenesis. J Virol. 2006; 80: 11418-31.

6. World Health Organization. Comprehensive Guideline for Prevention and Control for Dengue and Dengue Haemorrhagic Fever. Revised and expanded edition. Geneva: WHO; 2011.

7. Wati S, Li P, Burrell CJ, Carr JM. Dengue virus (DV) replication in monocyte-derived macrophages is not affected by tumor necrosis factor alpha (TNF-alpha), and DV infection induces altered responsiveness to TNF-alpha stimulation. J Virol. 2007; 81: 1016171.

8. Kou Z, Quinn M, Chen H, Rodrigo WW, Rose RC, Schlesinger JJ, et al. Monocytes, but not $\mathrm{T}$ or B cells, are the principal target cells for dengue virus (DV) infection among human peripheral blood mononuclear cells. J Med Virol. 2008; 80: 134-46.

9. Torsteinsdottir I, Arvidson NG, Hallgren R, Håkansson L. Monocyte activation in rheumatoid arthritis: increased integrin, Fc $\gamma$ and complement receptor expression and the effect of glucocorticoids. Clin Exp Immunol. 1999; 115: 554-60.

10. Veri MC, Gorlatov S, Li H, Burke S, Johnson S, Stavenhagen $\mathrm{J}$, et al. Monoclonal antibodies capable of discriminating the human inhibitory Fc $\gamma$ RIIB (CD32B) from the activating Fc $\gamma$ IIA (CD32A): biochemical, biological and functional characterization. Immunology. 2007; 121: 392-404.

11. García G, Sierra B, Pérez AB, Aguirre E, Rosado I, Gonzalez N, et al. Asymptomatic dengue infection in a Cuban population confirms the protective role of the RR variant of the FcgammaRIIa polymorphism. Trop Med Hyg. 2010; 82: 1153-6. 
12. Intansari US, Sukorini U, Sari SI. FcyRII (CD32) Monocytes in primary and secondary dengue infection. Indones J Clin Pathol Med Lab. 2015; 22: 42-7.

13. Hottz E, Tolley ND, Zimmerman GA, Bozza FA. Platelets in dengue infection. Drug Discov Today Dis Mech. 2011; 8: 33-8.

14. Kalayanarooj S, Vaughn DW, Nimmannitya S. Early clinical and laboratory indicators of acute dengue illness. J Infect Dis. 1997; 176: 313-21

15. Rubio GD, Torno LL. Association of leukocyte and thrombocyte counts as a predictor of bleeding outcomes among dengue patients. Phil J Microbiol Infect Di. 2007; 36: 33-8.

16. Soegijanto S. Patogenesa dan Perubahan Patofisiologi Infeksi Virus Dengue. Surabaya: Airlangga University Press; 2008.

17. Seneviratnea SL, Malavige GN, de Silva HJ. Pathogenesis of liver involvement during dengue viral infections. Trans R Soc Trop Med
Hyg. 2006; 100: 608-14.

18. Srikiatkhachorn A. Plasma leakage in dengue haemorrhagic fever. Thromb Haemost. 2009; 102: 1042-9.

19. Anderson R, Wang S, Osiowy C, Issekutz IC, et al. Activation of endothelial cells via antibody enhanced dengue virus infection of peripheral blood monocytes. J Virol. 1997; 71: 4226-32.

20. Suharti C. Dengue Hemorrhagic Fever in Indonesia: The Role of Cytokines in Plasma Leakage, Coagulation and Fibrinolysis [Dissertation]. Netherland: Nijmegen Universiteit; 2001.

21. Durbin AP, Vargas MJ, Wanionek K, Hammond SN, Gordon A, Rocha $\mathrm{C}$, et al. Phenotyping of peripheral blood mononuclear cells during acute dengue illness demonstrates infection and increased activation of monocytes in severe cases compared to classic dengue fever. Virology. 2008; 376: 429-35. 